\title{
Leveraging a lean region based on blockchain technology
}

\begin{abstract}
This article summarizes the arguments and counterarguments in the framework of the scientific discussion on the use of economical accounting in production, considering modern technologies of waste utilization. The main objective of the study is to conduct an analysis of the emergence of waste in various sectors of the national economy of Ukraine. The main ways of utilization of waste are determined. Systematization of literary sources and approaches to solving the problem allowed us to determine the problems of the operation of lean accounting and lean production. After analyzing the proposed problems of domestic and foreign scientists regarding the implementation of lean accounting, it is appropriate to conclude that the main obstacle to the establishment of a system of lean accounting is the lack of a definite methodological approach for the implementation of such a system. The urgency of solving this scientific problem is that to determine the ways of utilization of waste, it is necessary to keep an account of them considering the usefulness of the use of waste. An important area of research in the accounting system is the allocation of lean accounting and the latest concept of management of a production enterprise, which is aimed at eliminating the losses of production resources - lean production. The high level of organization of lean accounting is no longer a factor in achieving success, but the result. Obtaining a high level of organization of accounting processes (both basic and auxiliary) will allow the company to save a significant amount of resources. Among the fact that the concept of lean accounting involves fundamentally new approaches to the culture of management and accounting organization at the enterprise. Investigating the issue of conducting business operations related to the use of waste in production, its storage, utilization is necessary for the formation of a proper system of accounting and information support for the adoption of management decisions on the recycling the waste and the use of modern waste recycling technologies. The methodical tools of the conducted research were the methods of empirical analysis, the method of observation and generalization of the results of the conducted research. The research object was chosen by the industrial sector of Ukraine.
\end{abstract}

Keywords: lean accounting; production; waste; utilization; distributed registry.

Topicality of research. The current challenge for our country's population today is to comply with the provisions of EU Directive 1999/31/EC [1], which is aimed at being environmentally friendly, compliance with environmental legislation on the production and treatment of waste products, its utilization.

In order to comply with such provisions, in 2017 the National Strategy for Waste Management in Ukraine was approved for the period up to 2030 [2]. The adoption of this strategy should address the critical situation with waste in Ukraine, which developed during the accumulation, storage, processing and disposal of waste. The huge scale of resource costs and losses, the use of energy raw materials with outdated technologies in production affect the formation and accumulation of waste. All this contributes to the deepening of the ecological crisis and the emergence of important waste management problems. The managers of the enterprises and the accountants devote insufficient attention to the waste accounting at the enterprise and the utilization of waste. The high level of waste generation, low rates of its use and processing is due to the fact that insufficient attention is paid to the issue of reuse of resources, and the use of modern production technologies to eliminate all types of losses. At the same time, the detailed organization of the process of collection, storage, utilization and waste accounting will help not only to avoid penalties in the definition and recalculation and classification of waste, but also provides an opportunity to obtain accurate results in determining the financial results of industrial enterprises.

Industrial waste is produced in all sectors of the national economy of Ukraine, for example, in the mining industry and in ferrous and non-ferrous metallurgy (dust, rocks, rocks and water, methane, sludge, saline solutions, etc.). The construction industry is characterized by such wastes as construction waste, excavated soil during digging pits, a battle of building materials. For the metalworking and automotive industries, chemicals waste and paints are typical. In agriculture, the most waste can be converted into humus and fertilizers [3].

Considering the significant influence on the environment of the industrial enterprises of Ukraine and the formation and use of industrial waste products, there is a need to establish a control system for waste operations and production technologies, to reduce losses under conditions of resource constraints. It should focus on the functioning of a lean production and lean accounting.

At the same time, scientists are paying close attention to blockchain technology. The main advantage of blockchain technology over traditional accounting principles is that there is no need on the part of the state to 
perform operations at the enterprise. Blockchain does not have a central authority, so transactions are audited by all members of the system. This simplifies the procedure and eliminates intermediaries. The network code is open and anyone can contact it, but personal information is kept confidential. All the block creators see the data for each specific operation. That is, in the future it may be possible to rate enterprises with respect to the implementation of waste disposal operations. Therefore, an important area of research in the accounting system is the allocation of lean accounting and the latest management concept of a production enterprise, which is aimed at eliminating the losses of production resources - a lean production.

Analysis of the recent research and publications. The problems of introducing lean accounting and lean production in researches of domestic scientists and in practice are not enough. The question of estimating the value of industrial waste in the works was investigated by Zamula I.V., Legenchuk S.F., Koryagin M.V., Oliynyk Ya.B., Romanchuk K.V., Saran V.V.

At the same time, it should be noted that he works of some scientists, for example V.V. Pikiner, devoted to the problems of assessing the value of waste, especially the question of the reliability of measuring the value. In his understanding of waste, the author focuses on the fact that in order to benefit from waste in the future, it is necessary to evaluate its value, but this is possible only in return waste. For example, at the enterprises of the food industry, the return waste is not accounted or evaluated and accounted not at the time of its formation, but only after its actual use, when it is already certain which part of it will be used for own needs or sold to other enterprises. That is, the recognition of return waste is expedient at fair value using the market method [4]. Romanchuk K.V., Shymanska K.V. studied the system of normative regulation of economic operations with waste. They determined the composition of business operations of the enterprise in each process of waste management. It is emphasized that companies demand additionally the costs of implementing resource-saving and innovative waste recycling technologies [5]. Gurina N.V. classified waste wood processing at enterprises. She has suggested entering a separate account 29 «Secondary material resources» with the division into analytical accounts. The author assures that in this industry you can use all waste in your own production from sawdust to veneer segments [6].

Koryagin M.V. and Chick M.Yu. in their research found that ten steps should be made to introduce a system of lean accounting into the enterprise. By studying the work of foreign scientists in this area, the well-founded ideas in the field of «lean accounting» are the work of Bruce L. Baggaley, Larry Grasso, Brian H. Maskell, as noted by the national scientists [7].

After analyzing the proposed problems of national and foreign scientists regarding the implementation of lean accounting, it is appropriate to conclude that the main obstacle to the establishment of a system of lean accounting is the lack of a definite methodological approach for the implementation of such a system.

The purpose of the article. The purpose of this article is to study the system of «lean accounting and lean manufacturing». It is necessary to analyse the waste accounting at the enterprise and how to dispose of it; to investigate the problems of establishing a lean accounting at the enterprise; to influence administrative decisions on the accounting system, on waste recycling.

Presentation of the material. The basis of lean accounting is the concept of «lean manufacturing». Such concept is first formulated in Japanese enterprises and has many success factors. Japan for its successful development chose a harmonious combination of traditions with completely new approaches to the organization of financial and economic activity. It pays more attention to utilization and recycling waste.

Today, in the world market, Japan is a supplier of products, characterized by complex science-intensive industries, modern structural materials. Therefore, national enterprises need to take over the experience of financial and economic activities of Japan and other leading foreign countries.

Blockchain-owned states themselves also tend to turn to Ethereum. In 2018, Brazil decided to use a platform for processing petitions. Canada provides its citizens with information on the use of government grants through the Ethereum blockchain to reduce the risks of corruption. Switzerland registers digital identification documents on the Ethereum network, and Chile uses it to track data in its energy systems.

The high level of organization of lean accounting is no longer a factor in achieving success, but the result. Obtaining a high level of organization of accounting processes (both basic and auxiliary) will allow the company to save a significant amount of resources. Among the fact that the concept of lean accounting involves fundamentally new approaches to the culture of management and accounting organization at the enterprise, it also offers a set of tools that allow you to cheapen and speed up the accounting processes. The main accounting tools are the following: just in time, the «Six Sigma» concept, Kaizen (Continuous Improvement Concept), Value Stream Management, Pokéeca (Error-Protecting Method) etc. In this list, practitioners highlight «value stream management» as one of the most effective tools in achieving goals.

A common feature of the «Six Sigma» concept that emerged in the United States and the concept of «lean manufacturing» that originated in Japan is the joint economic interest in a business process, namely the relation of Japanese manufacturers to the process production, resource savings and recycling. This essentially distinguishes it from many previous economic concepts, which are guided by the overall impact on the financial and economic activities of the business entity and relates to the economic concepts of the new generation, such 
as «business process reengineering». Therefore, the concept of «Six Sigma» and the concept of «lean production» perfectly complement each other [8].

What are the main problems of the concept of «lean manufacturing» that can be solved by the concepts of «six sigma»?

1. The concept of «lean manufacturing» does not establish requirements for the form of implementation of the concept and the necessary economic instruments. Therefore, the success of the concept of «lean manufacturing» largely depends on the initiative of the organizational capabilities of accountants, but with the change of manager, the implementation of the concept of «lean manufacturing» can be crashed. The concept of «lean manufacturing» lacks formalized commitments from the top management, formalized training, planned allocation and allocation of resources, tracking the success in relation to accepted corrective economic actions, etc. All these questions are grounded in the concept of «six sigma» («Six Sigma»).

2. The concept of «lean manufacturing» is not sufficiently focused on the issues of users (both internal and external). Its solution is not directly related to the main purpose of the concept - the elimination of losses and non-production costs. In the «Six Sigma» concept, a focuse on users is a key element. This is confirmed by the fact that all the basic postulates of this concept are built on tracking the relationship between the parameters of the business process and the characteristics of products with specifications that are set by users. The key concept of the «Six Sigma» concept (DMAIC) begins with the definition of user needs: Define, Measure, Analyze, Improve and Control.

3. In the concept of «lean manufacturing» defects and inconsistencies are recognized as one of the main sources of losses in the enterprise. At the same time, this concept does not consider the methods of statistical management of business processes to eliminate losses. The concept of «lean manufacturing» is not focused on finding sources of business variability and ways to reduce variability, which is one of the key elements of the concept of «six sigma».

What are the main problems of the concept of the «Six Sigma» that can be solved by the postulates of the concept of «lean manufacturing»?

1. Defects - the main objective of the «Six Sigma» concept is just one of many types of enterprise losses. In the classical theory of the concept of lean accounting, seven types of losses are distinguished: overproduction, waiting, transportation, activity, which does not create additional value, the presence of inventory balances, personnel turnover, and production of defects. Other scientists allocate additional types of losses. For example, «unjustified savings», which is to use cheap and poor-quality raw materials; «multivariate construction of business processes» as a result of the use of unlicensed elements in business processes.

2. In the «Six Sigma» concept, it is not possible to draw parallels between the quality and satisfaction of user interests, on the one hand, the length and speed of the execution of business processes, on the other hand. At the same time, the duration of business processes is directly related to the satisfaction of the interests of users in obtaining services, and for business processes of production - with assets in the form of unused stocks. In the concept of «lean manufacturing», time analysis is a key focus as one of the main resources of the business process.

3. A set of six sigma concepts limits the space available for tasks that can be solved. The improvement of business processes within the framework of the «Six Sigma» concept is mainly through reducing the variability of business processes by statistical methods and re-designing business processes using the DFSS method (Design for «Six Sigma»). The «Six Sigma» concept does not consider such opportunities for improving business processes as reducing non-productive business activities, waiting time (idle time), reducing inventory and transport costs, optimizing workplaces, etc. All of the above-mentioned capabilities are fully realized by the concept of «Lean Manufacturing».

Thus, «Lean Manufacturing» is to involve every employee of the company in the process of optimizing the business processes and maximizing the focus on meeting the needs of consumers. The basic requirement of consumers in the XXI century is the satisfaction of needs through the payment for the finished products consumed, not for waste. That is, in forming and managing production costs and determining the cost of production, all associated costs, namely those that are related to the processing, the correction of the deficit, the partial waste disposal costs are transferred to the consumer. For example, in 2005, in a small bakery in Barcelona, the problem associated with the industrial power crisis was solved using a technology of lean accounting and production. Bakery owners believed that waste recycling and its use are the key to expansion and business development. A little later, namely in 2010, the owners decided to transfer their experience of managing a small business to the community and released the book «The Lean Bakery» [9, 10] The main ideas for the introduction of lean manufacturing, or the problem of lean production, are the elimination of waste; increasing the role of workers; reduction of stocks; increasing productivity with respect to the quality level. Brian $\mathrm{H}$. Maskell notes that the current functioning of the accounting system in production is understandable only to some workers of the enterprise. The new accounting system should eliminate the ambiguity of accounting for waste from accounting processes and carefully compiling the financial report. The system must comply with GAAP accounting principles and internal reporting requirements. Financial and non-financial reporting should reflect 
both the overall flow of cost processes in the enterprise and on a single product. It is important in the construction of such a system and the conduct of modern domestic enterprises to remove processes that do not affect the increase in the cost of production. Proceeding from this, we offer the following functional scheme of the system of lean accounting in the production taking into waste accounting.

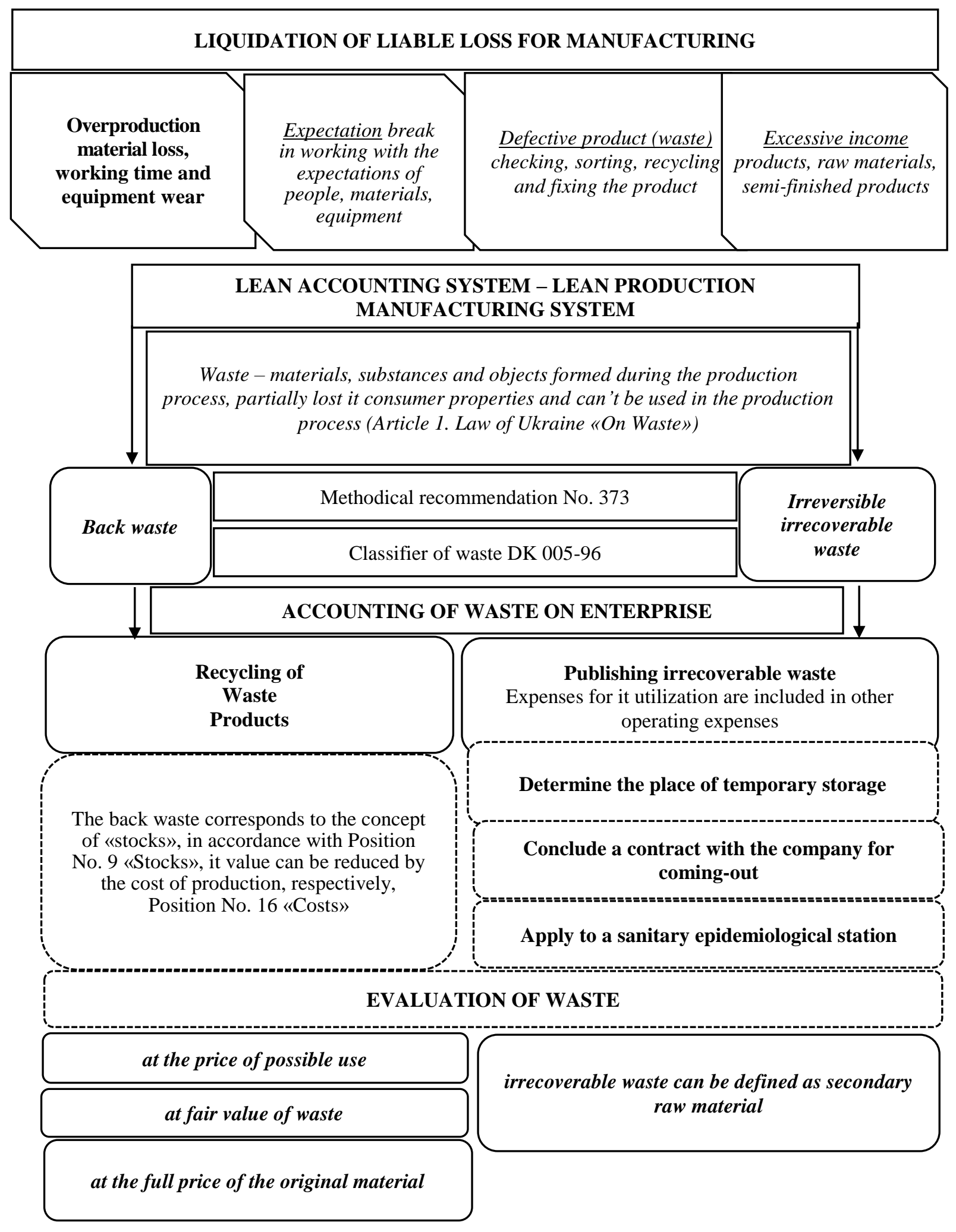

Source: developed by authors based on [11-14]

Figure 1. Functional scheme of the lean accounting system at the enterprise 
For example, exceeding the supply of products over its demand leads to an increase in stocks, which slows down the turnover of working capital. Often, this is a crisis in the economy, defined as overproduction, characterized by the loss of material resources, labour resources, and wear of equipment. In case of overproduction, the company loses its resources, and the goal of the sale of finished (produced) products will never be achieved. Elimination of such a process as a loss in production allows establishing continuous production, as people receive wages during idle time (not by the fault of the worker) [15].

The accounting information is important in the management of the enterprise. The conducted research made it possible to establish the fact that only waste materials are recycled. Because they have utility that can still be used. It is possible to estimate such usefulness in three ways, namely: at the price of possible use, at fair value, at the full price of the primary material. Sewage can only be evaluated as a second raw material. It turns out that in order to utilize the waste at the enterprise, it is necessary to carry out several measures aimed at preserving the ecological state of the environment, safe storage and the recycling process itself. For example, the construction company of Ukraine ARMMETAL carries out primary utilization of construction materials. When obtaining cement as finished product, concomitant products such as blast furnace slag, walnut cobs, blade dust are used as a minimizer when burning cement clearing, which reduces the temperature regime of this process. Utilization of sewage and coal-mining enterprises of Ukraine, for example, SD «Dneprovskoe» of DTEK Pavlohradvugil shows that pumping water occurs in three stages. At the first stage, the pumping water is carried out from the mine shaft to the main barrel (for example, the depth of the barrel is 612 meters, 340 meters). At the second stage, water from the main trunk is pumped to the horizons closer to the surface (for example, the $200 \mathrm{~m}$ horizon on which there is a capacity for pumped water), since the power of the pumps is not enough to pump water from the depths to the mine septic tanks. But at the third stage, pumping water comes from the tank to the mine septic tanks. In the mine pond, the water is cleaned (chlorination of water is carried out). For use of water for technical purposes, water from sediment pumping stations is pumped into a container located in a mine yard. Such water is used in everyday life, pumped to the administrative-household complex, where it will be used in the future in the laundry, pumping water into reservoirs, which are used during extinguishing of waste heaps.

The purified mine water is discharged into the rivers of the Azov and Black Seas. The share of the Azov Sea accounts for about $80 \%$ of the total mine water of the coal industry 106. In the Black Sea basin, Ukraine's coal enterprises are dumping about 115 million cubic meters of water. Thus, coal mining enterprises are faced with the task of switching to the technology of preserving the natural resource potential to provide the vital needs of present and future generations. At present, in Ukraine, one of the promising areas in the field of processing waste heaps (waste heaps) for metallurgy is the use of hollow breeds as raw materials for the manufacture of refractory materials. In addition, in recent years the waste heaps of enterprises producing coal of the anthracite group are recycled, thus extracting a concentrate (coal tar) with an Ad content of as much as $15 \%$, which can then also be realized. The use of lean accounting at Ukrainian enterprises will allow us to realize the concept of sustainable development for our state. Implementation at the enterprises of lean production will allow manufacturing products in conditions of resource constraints. It will also allow eliminating business processes that do not produce any utility. The introduction of such a system requires further theoretical and methodological research by the scientists.

Conclusion. In most enterprises, where prospects of implementation of «lean accounting» were investigated, a number of features were established.

Firstly, enterprises are aiming at a quick result from the introduction of lean accounting tools that would not radically change the situation in the enterprise and would not require changes at the level of senior management of enterprises. Secondly, enterprises are ready to invest significant resources in technology and equipment, which, according to managers, provide a significant leap, while continuous and gradual improvement is a long process with a vague economic effect. Thirdly, industrial enterprises that plan to implement lean accounting tools underestimate the importance of the philosophy of «lean manufacturing». Toyota's bottom line is the philosophy of lean manufacturing, which involves a profound and comprehensive cultural transformation. This is philosophy of the long-term perspective, the correct process gives correct results, increasing the value of the organization through the development of employees and partners, and the constant solution of fundamental problems stimulates the continuous learning of organizations n) [16]. If «lean accounting» begins to use simple tools with a fast result and philosophy, which leaders are executives, then the company's staff is convinced in the effectiveness of «lean accounting», then changes the mindset and culture, which allows you to proceed to the introduction of more complex tools, and the cycle is repeated. The formation and functioning of the system of thrifty accounting will require further research in this direction from the scientists and greater interest from the leaders and owners of enterprises.

One more important point is the blockchain overhaul for the healthy operation of the operating system in the region, which is very useful and convenient. The mechanism of smart contracts for the automation of operations is possible. As for the blockchain registry, there are legal rights to record, say, about manifestations of the right of way, then the mechanism of transmission of ownership, and by the day, the procedure for registering a new hairline before registering, you can make a special smart program. Later, we'll spend more time on the side of the country, controlling the hats and disposing them at that time. 


\section{References:}

1. Директива Ради № 1999/31/СС щодо полігонів захоронення відходів [Електронний ресурс]. - Режим доступу : http://zakon.rada.gov.ua/laws/show/994_925.

2. Про схвалення Національної стратегії управління відходами в Україні до 2030 року : розпорядження КМУ [Електронний ресурс]. - Режим доступу : http://zakon.rada.gov.ua/laws/show/820-2017-\%D1\%80.

3. Замула I.В. Облік виробничих відходів як фактор забезпечення раціонального природокористування / I.B. Замула // Вісник Житомирського державного технологічного університету. Серія : Економічні науки. 2009. - № 1 (47). - C. 48-50.

4. Пікінер В.В. Проблеми визнання та оцінки відходів в бухгалтерському обліку в контексті соціально відповідального управління підприємствами / B.B. Пікінер // Ефективна економіка. - 2015. - № 8.

5. Романчук К.В. Напрями облікового забезпечення та регулювання господарських операцій підприємств у сфері поводження з відходами / К.В. Романчук, К.В. Шиманська. - 2013.

6. Chiarini A. Lean production: mistakes and limitations of accounting systems inside the SME sector / A.Chiarini // Journal of Manufacturing Technology Management. - 2012. - T. 23. - № 5. - C. 681-700.

7. Корягін M.B. Lean облік - як облікова система майбутнього / M.B. Корягін, M.Ю. Чік // Проблеми теорії та методології бухгалтерського обліку, контролю і аналізу. - 2017. - Т. 38. - № 3.

8. Juan Antonio Tena The Lean Bakery / Juan Antonio Tena, Emi Castro [Електронний ресурс]. - Режим доступу : https://www.lean.org/Bookstore/ProductDetails.cfm?

9. Pepper M.P.J. The evolution of lean Six Sigma / M.P.J. Pepper, T.A. Spedding // International Journal of Quality \& Reliability Management. - 2010. - T. 27. - № 2. - C. 138-155.

10. Brian H. Maskell Lean Accounting Elevator Speech / H.Brian Maskell [Електронний ресурс]. - Режим доступу : http://www.maskell.com/lean.

11. Класифікатор ДК 005-96 - Державний класифікатор України. Класифікатор відходів ДК 005-96, затверджений наказом Держстандарту від 29.02 .96 р. № 89.

12. Методрекомендації № 373 - Методичні рекомендації з формування собівартості продукції (робіт, послуг) у промисловості, затверджені наказом Мінпромполітики України від 09.07.2007 р. № 373.

13. П(С)БО 9 - Положення (стандарт) бухгалтерського обліку 9 «Запаси», затверджене наказом Мінфіну України від 20.10.99 р. № 246.

14. П(С)БО 16 - Положення (стандарт) бухгалтерського обліку 16 «Витрати», затверджене наказом Мінфіну України від 31.12.99 p. № 31.

15. Kinkel $S$. Trends in production relocation and backshoring activities: changing patterns in the course of the global economic crisis / S.Kinkel // International Journal of Operations \& Production Management. - 2012. - T. 32. № 6. - C. 696-720.

16. Усатенко О. Взаємодія системи управлінської звітності з прийняттям управлінських рішень: причиннонаслідкові зв'язки в обліку стартапів / О.Усатенко, А.Макурін // Облік і фінанси. - 2019. - Т. 84. - С. 54-60.

\section{References:}

1. Dyrektyva Rady No. 1999/31/JeS shhodo poligoniv zahoronennja vidhodiv (1999), [Online], available at: http://zakon.rada.gov.ua/laws/show/994_925

2. KMU, Pro shvalennja Nacional'noi' strategii' upravlinnja vidhodamy v Ukrai'ni do 2030 roku, rozporjadzhennja, [Online], available at: http://zakon.rada.gov.ua/laws/show/820-2017-\%D1\%80

3. Zamula, I.V. (2009), «Oblik vyrobnychyh vidhodiv jak faktor zabezpechennja racional'nogo pryrodokorystuvannja», Visnyk Zhytomyrs'kogo derzhavnogo tehnologichnogo universytetu, Serija Ekonomichni nauky, Vol. 1 (47), pp. 48-50.

4. Pikiner, V.V. (2015), «Problemy vyznannja ta ocinky vidhodiv v buhgalters'komu obliku v konteksti social'no vidpovidal'nogo upravlinnja pidpryjemstvamy», Efektyvna ekonomika, No. 8.

5. Romanchuk, K.V. and Shymans'ka, K.V. (2013), «Naprjamy oblikovogo zabezpechennja ta reguljuvannja gospodars'kyh operacij pidpryjemstv u sferi povodzhennja z vidhodamy», Visnyk Zhytomyrs'kogo derzhavnogo tehnologichnogo universytetu, Serija Ekonomichni nauky, Vol. 3 (27), pp. 281-296.

6. Chiarini, A. (2012), «Lean production: mistakes and limitations of accounting systems inside the SME sector», Journal of Manufacturing Technology Management, Vol. 5 (23), pp. 681-700.

7. Korjagin, M.V. and Chik, M.Ju. (2017), Lean oblik - jak oblikova systema majbutn'ogo, Problemy teorii' ta metodologii', buhgalters'kogo obliku, kontrolju i analizu. Vol. 38, No. 3.

8. Tena, Juan Antonio and Castro, Emi (2017), The Lean Bakery, [Online], available at: https://www.lean.org/Bookstore/ProductDetails.cfm?

9. Pepper, M.P. and Spedding, T.A. (2010), «The evolution of lean Six Sigma», International Journal of Quality \& Reliability Management, Vol. 27 (2), pp. 138-155.

10. Brian H. Maskell (2017), Lean Accounting Elevator Speech, [Online], available at: https://maskell.com/What-islean-accounting

11. Klasyfikator DK 005-96 - Derzhavnyj klasyfikator Ukrai'ny. Klasyfikator vidhodiv DK 005-96, zatverdzhenyj nakazom Derzhstandartu vid 29.02.96 r., No. 89, [Online], available at: http://plast.vn.ua/DK005-96.html

12. Metodrekomendacii' № 373 - Metodychni rekomendacii' z formuvannja sobivartosti produkcii' (robit, poslug) $u$ promyslovosti, zatverdzheni nakazom Minprompolityky Ukrai'ny vid 09.07.2007 r., No. 373, [Online], available at: http://consultant.parus.ua/?doc=00XJAFEA86 
13. $P(S) B O 9$ - Polozhennja (standart) buhgalters'kogo obliku 9 «Zapasy», zatverdzhene nakazom Minfinu Ukrai'ny vid 20.10.99 r., No. 246, [Online], available at: http://zakon.rada.gov.ua/laws/show/z0751-99

14. $P(S) B O 16$ - Polozhennja (standart) buhgalters'kogo obliku 16 «Vytraty», zatverdzhene nakazom Minfinu Ukrai'ny vid 31.12.99 r., No. 31, [Online], available at: http://zakon.rada.gov.ua/laws/show/z0751-99

15. Kinkel, S. (2012), «Trends in production relocation and backshoring activities: changing patterns in the course of the global economic crisis», International Journal of Operations \& Production Management, Vol. 32, Issue 6, pp. $696-720$.

16. Usatenko, O. and Makurin, A. (2019), «Interaction of the management system with the adoption of management decisions: cause-and-effect management in the start-up area», Oblik i finansy, Vol. 84, pp. 54-60.

Чік Марія Юріївна - кандидат економічних наук, доцент кафедри бухгалтерського обліку Львівського торговельно-економіного університету.

Наукові інтереси:

- бережливий облік та етапи його впровадження в Україні;

- особливості проведення аудиту на вітчизняних підприємствах.

E-mail marija_chik@ukr.net

Макурін Андрій Андрійович - докторант кафедри фінансів, банківської справи та страхування Харківського державного університету харчування та торгівлі, кандидат економічних наук, асистент кафедри обліку і аудиту Національного технічного університету «Дніпровська політехніка».

Наукові інтереси:

- бережливий облік та етапи його впровадження в Україні;

- віртуальні грошові кошти та система розподіленого реєстру.

E-mail: makurin.a.a@nmu.one 